\title{
Protocol
}

\section{Mounting Live Cells onto Microscope Slides}

\author{
Brad Chazotte
}

\section{INTRODUCTION}

This protocol describes the mounting of cells which have been grown on cleaned coverslips in cell culture dishes containing the appropriate medium and supplements. Labeling is performed with the coverslips placed in culture dishes. After cells are labeled, the coverslips can be mounted onto microscope slides to be viewed for short-term observation of live cells or longer-term observation of fixed cells. For viewing live cells for longer periods of time, specialized chambers should be used in which suitable growth conditions can be maintained.

\section{MATERIALS}

CAUTIONS AND RECIPES: Please see the end of this protocol for appropriate handling of materials marked with $<!>$, and recipes for reagents marked with $<R>$.

\section{Reagents}

Cells of interest, grown on coverslips and labeled with fluorescent probe(s)

$<\mathrm{R}>$ Phosphate-buffered saline (PBS)

Prepare PBS with added $\mathrm{CaCl}_{2}$ and $\mathrm{MgCl}_{2}\left(\mathrm{PBS}^{+}\right)$. This solution allows cells to adhere to each other and to the substrate. If cells are in medium containing no $\mathrm{Ca}^{2+}$ or $\mathrm{Mg}^{2+}$, they will round up and detach from the substrate.

Hanks' balanced salt solution (HBSS) with $\mathrm{Ca}^{2+}$ and $\mathrm{Mg}^{2+}$ but no phenol red (Invitrogen 14025-092) can be used instead of $\mathrm{PBS}^{+}$(see Step 1 note).

$<$ R $>$ Valap

The wax mixture should spread smoothly and dry quickly on a glass slide. If it hardens too quickly, add more Vaseline and lanolin; if it does not harden quickly enough, add more paraffin.

\section{Equipment}

Cell culture dishes, sterile

Cotton swabs

Hot plate

Use to maintain Valap at the proper temperature.

Incubator, water-jacketed and $\mathrm{CO}_{2}$-regulated

Microscope, fluorescence

Microscope slides, cleaned

Alternatively, commercially available specialized chambers can be used on which to mount coverslips for imaging.

Parafilm

Tweezers, fine

Adapted from Imaging: A Laboratory Manual (ed. Yuste). CSHL Press,

Cold Spring Harbor, NY, USA, 2010.

Cite as: Cold Spring Harb Protoc; 2011; doi:10.1101/pdb.prot5554

www.cshprotocols.org 
1. Using fine tweezers, transfer live cells that have been grown on coverslips and labeled to a dish of $\mathrm{PBS}^{+}$(or the desired cell culture medium).

Some cell culture media supplements, such as phenol red, can interfere with fluorescence observation. PBS $^{+}$ or HBSS with $\mathrm{Ca}^{2+}$ and $\mathrm{Mg}^{2+}$ but no phenol red are frequently used when observing fluorescence to reduce or eliminate this problem. If cells are fixed before mounting, they can be mounted in commercially available aqueous mounting medium.

2. Place narrow strips of Parafilm onto a microscope slide, positioned so that the coverslip will fit between them with two parallel edges of the coverslip extending onto the Parafilm strips.

The Parafilm serves as a spacer, which prevents live cells from being crushed. Cells that are fixed before mounting do not require spacers.

3. Transfer the coverslip to the prepared slide.

4. Using a cotton swab, seal the coverslip around its edges with melted Valap.

Avoid using commercial slide sealants that contain organic solvents (e.g., acetone), because they can be detrimental to live cells.

5. Image the cells using fluorescence microscopy.

See Troubleshooting.

\section{TROUBLESHOOTING}

Problem: Images are blurred, distorted, or lacking in contrast.

[Step 5]

Solution: Poor-quality images can result from using plastic. This is particularly a problem when phase-contrast or differential interference contrast microscopy is used. It can also be a problem for transmitted light images on confocal microscopes. Some plastics interfere with fluorescence only at certain wavelengths. To avoid this problem, grow cells on optical-quality glass; \#1.5 microscope coverslips are optimal for most uses. There are also optical-quality cell culture dishes available for situations when coverslips and slides are not feasible.

\section{ACKNOWLEDGMENTS}

I thank my wife, Nancy, and my daughter, Bryanna, for their patience while I was writing this article. I dedicate this article in memory of my mother, Cozette Chazotte, 1919-2009.

\section{RECIPES}

[NOTE: Recipes for reagents marked with the $<R>$ symbol not listed below can be found online at http://www. cshprotocols.org/recipes.]

\section{Phosphate-buffered saline (PBS)}

\begin{tabular}{lllll}
\hline Reagent & $\begin{array}{l}\text { Amount to add } \\
\text { (for 1X solution) }\end{array}$ & $\begin{array}{l}\text { Final concentration } \\
(1 \mathrm{X})\end{array}$ & $\begin{array}{l}\text { Amount to add } \\
\text { (for 10X stock) }\end{array}$ & $\begin{array}{l}\text { Final concentration } \\
(10 X)\end{array}$ \\
\hline $\mathrm{NaCl}$ & $8 \mathrm{~g}$ & $137 \mathrm{mM}$ & $80 \mathrm{~g}$ & $1.37 \mathrm{M}$ \\
$<!>\mathrm{KCl}$ & $0.2 \mathrm{~g}$ & $2.7 \mathrm{mM}$ & $2 \mathrm{~g}$ & $27 \mathrm{mM}$ \\
$\mathrm{Na}_{2} \mathrm{HPO}_{4}$ & $1.44 \mathrm{~g}$ & $10 \mathrm{mM}$ & $14.4 \mathrm{~g}$ & $100 \mathrm{mM}$ \\
$\mathrm{KH}_{2} \mathrm{PO}_{4}$ & $0.24 \mathrm{~g}$ & $1.8 \mathrm{mM}$ & $2.4 \mathrm{~g}$ & $18 \mathrm{mM}$ \\
If necessary, PBS may be supplemented with the following: & & \\
$<!>\mathrm{CaCl}_{2} \cdot 2 \mathrm{H}_{2} \mathrm{O}$ & $0.133 \mathrm{~g}$ & $1 \mathrm{mM}$ & $1.33 \mathrm{~g}$ & $10 \mathrm{mM}$ \\
$<!>\mathrm{MgCl}_{2} \cdot 6 \mathrm{H}_{2} \mathrm{O}$ & $0.10 \mathrm{~g}$ & $0.5 \mathrm{mM}$ & $1.0 \mathrm{~g}$ & $5 \mathrm{mM}$
\end{tabular}

$<$ ! > PBS can be made as a $1 \mathrm{X}$ solution or as a 10X stock. To prepare $1 \mathrm{~L}$ of either $1 \mathrm{X}$ or $10 \mathrm{X}$ PBS, dissolve the reagents listed above in $800 \mathrm{~mL}$ of $\mathrm{H}_{2} \mathrm{O}$. Adjust the $\mathrm{pH}$ to 7.4 (or 7.2, if required) with $\mathrm{HCl}$, and then add $\mathrm{H}_{2} \mathrm{O}$ to $1 \mathrm{~L}$. Dispense the solution into aliquots and sterilize them by autoclaving for $20 \mathrm{~min}$ at $15 \mathrm{psi}\left(1.05 \mathrm{~kg} / \mathrm{cm}^{2}\right)$ on liquid cycle or by filter sterilization. Store PBS at room temperature. 


\section{Valap}

Add equal weight of lanolin, Vaseline (or other petroleum jelly), and paraffin together in a 1-liter beaker. Heat mixture at a low setting on a hot plate. Stir occasionally until thoroughly blended.

Aliquot into several small screw-capped jars ( $50-\mathrm{ml}$ capacity). Store at room temperature.

\section{CAUTIONS}

[NOTE: For reagents marked with the <!> symbol not listed below, please consult the manufacturer's Material Safety Data Sheet for further information.]

$\mathrm{CaCl}_{2}$ (Calcium chloride) is hygroscopic and may cause cardiac disturbances. It may be harmful by inhalation, ingestion, or skin absorption. Do not breathe the dust. Wear appropriate gloves and safety goggles.

$\mathrm{HCl}$ (Hydrochloric acid, Hydrochloride) is volatile and may be fatal if inhaled, ingested, or absorbed through the skin. It is extremely destructive to mucous membranes, upper respiratory tract, eyes, and skin. Wear appropriate gloves and safety glasses. Use with great care in a chemical fume hood. Wear goggles when handling large quantities.

$\mathrm{KCl}$ (Potassium chloride) may be harmful by inhalation, ingestion, or skin absorption. Wear appropriate gloves and safety glasses.

$\mathrm{MgCl}_{2}$ (Magnesium chloride) may be harmful by inhalation, ingestion, or skin absorption. Wear appropriate gloves and safety glasses and use in a chemical fume hood. 


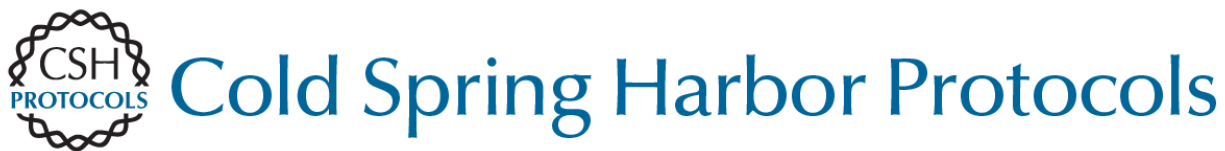

\section{Mounting Live Cells onto Microscope Slides}

Brad Chazotte

Cold Spring Harb Protoc; doi: 10.1101/pdb.prot5554

\begin{tabular}{|c|c|}
\hline $\begin{array}{r}\text { Email Alerting } \\
\text { Service }\end{array}$ & Receive free email alerts when new articles cite this article - click here. \\
\hline $\begin{array}{r}\text { Subject } \\
\text { Categories }\end{array}$ & $\begin{array}{l}\text { Browse articles on similar topics from Cold Spring Harbor Protocols. } \\
\text { Cell Biology, general (1382 articles) } \\
\text { Cell Culture (301 articles) } \\
\text { Cell Imaging (525 articles) } \\
\text { Imaging/Microscopy, general (579 articles) } \\
\text { Labeling for Imaging (339 articles) } \\
\text { Live Cell Imaging (274 articles) } \\
\text { Visualization (524 articles) } \\
\text { Visualization, general (369 articles) }\end{array}$ \\
\hline
\end{tabular}

